\title{
MAYO Index for Deep Analytics of Price and Performance of IPL Players
}

\author{
C. Deep Prakash \\ Department of Electrical Engg. \\ Dayalbagh Educational \\ Institute \\ Agra, India - 282005
}

\author{
C. Patvardhan \\ Department of Electrical Engg. \\ Dayalbagh Educational \\ Institute \\ Agra, India- 282005
}

\author{
C. Vasantha Lakshmi \\ Department of Physics and CS \\ Dayalbagh Educational \\ Institute \\ Agra, India - 282005
}

\begin{abstract}
In this paper, a new MAYO Index is presented for deeper analytics of the price and performance of IPL players in IPL season IX. The MAYO index is comprehensive in terms of including both price and performance in one index. This is in contrast to the popular indices like batting and bowling averages and MVPI that only measure performance. The index is created with the help of machine learning technique called Random Forests. The analytics provide deeper insight into the complex problem of understanding how the performance of the players of different franchises and countries was and provides clues for better management practices in terms of player acquisition. The players to watch for in future are clearly identified and so are those who did not perform according to expectations.
\end{abstract}

\section{General Terms}

Algorithms, Machine Learning, Data Analytics

\section{Keywords}

Cricket, IPL, Random Forests, Data Analytics

\section{INTRODUCTION}

Indian Premier League (IPL), a T20 tournament, was started in 2008 by Board of Control of Cricket in India (BCCI) [1]. Eight franchises were assigned to eight of the largest cities in India. The teams in IPL were franchisee driven. The players were selected through competitive bidding from a pool of available players. BCCI has been organizing the IPL T20 cricket tournament in each year. 9 IPL tournaments have been held till date.

Some studies related to cricket reported in the literature include determination of optimal batting strategies using dynamic programming, alternative batting averages when the batsman remains not-out in one-day cricket, determination of optimal batting order, analysis of player performance using Duckworth/Lewis percentage values etc [2-6]. Player evaluation is one very important aspect in IPL [7]. Indices have also been developed to evaluate the performance ranking of the player [8-9] and for team selection [10-11]. These ranking indices were purely performance based.

When a big league like IPL is analyzed, money is a crucial factor as well. Each franchisee invests huge amounts in players who are expected to perform well and win matches for their teams. The franchisees have their game plan. They evaluate the performances of players according to their requirements and invest money. There is usually a difference in the predicted and actual performance of a player in a particular tournament. In the case of IPL, a player typically has some base price and the franchisee acquires the player by paying a price that is equal to or more than the base price. The amount of money the franchisee pays more than the base prize for a particular player depends on what the franchisee expects his performance would be in the IPL. This expectation is based on their analysis of the player's record and current form.

When one wishes to study price-performance of players in IPL 9 several logical questions arise. These are as follows:

- Who are the top performers in batting and bowling?

- Which players performed according to or better than expectations and which did not?

- Which players performed much better than what was suggested by their price tags? Much worse?

- What was the performance of the foreign players relative to Indian players? Does performance differ country wise?

- Could franchisee be better off in investing in promising Indian players who command a much smaller price and deliver performance rather than the expensive overseas stars who deliver little?

- How does the acquisition strategy of different franchisees get reflected in the performance distributions according to price and performance?

When performance of a player is evaluated in an IPL tournament it is important to look at both the cricketing as well as financial aspects. A highly priced player is obviously expected to perform very well. He would cause a flutter only if he does not perform. But the ones that are to be watched out for are those who are relatively less expensive and yet perform well. It is not reasonable to expect that their performance would be of the same level as the top grossers. They, however, may be a better value for money proposition. Accordingly, in this work, a new comprehensive index that considers both cricketing and financial aspects especially in the context of IPL is proposed. The index is called the Most Amazing Yield Observation (MAYO) index. The idea is to capture in a single index the difference between expectations and real performance according to the price commanded. Some of the insights that the MAYO index provides are quite unexpected and not so obvious and, hence, the name.

The rest of the paper is organized as follows. In section 2, a ranking methodology to find the difference between the actual performance and the predicted performance is given. In section 3, the methodology of calculating the MAYO Index is given. In section 4 the results and discussions are given and in section 5 the conclusions are given and in section 6 the references are given. 


\section{PERFORMANCE EVALUATION METHODOLOGY FOR IPL}

A strong mathematical model for performance ranking evaluates the relative performance of the players and enables an ordering to be imposed for determining the better player in a pair-wise comparison. The often quoted index in the case of IPL is the Most Valuable Player Index (MVPI) popularized by Rediff Cricket [12]. The MVPI for a player is the sum of his batting points and bowling points.

MVPI Batting $=[($ Player's Batting Average/Tournament Batting Average)*Runs Scored + (Player's Batting Strike Rate / Tournament Batting Strike Rate)]* Runs Scored

MVPI Bowling $=[($ Tournament Bowling Average/Player's Bowling Average) + (Tournament Bowling Economy Rate/Player's Bowling Economy Rate) ${ }^{* 2}$ ] * Wickets Taken

Deep Performance Index [8] ranks the bowlers and batsmen based on their performance in the IPL up to season VII and their performance in T20 matches overall up to that point in time. However, T20 is an evolving game [9]. In this paper, DPI formula is determined through recursive feature elimination by taking data up to season 9 [13,14] for predicting the performance in IPL Season 9 and the actual performance statistics of IPL season 9 for calculating the actual performance ranking.

In order to evaluate the batting capability in T20, eight indices are considered as follows.

1) HardHitter $=(4 *$ Fours $+6 *$ Sixes $) /$ Balls faced by player

2) Finisher $=$ Number of times Not Out/ Total number of played Innings

3) FastScorer $=$ Total runs scored/ Total balls faced

4) Consistent $=$ Total runs scored/ Total number of innings in which he got out

5) RunningBetweenWickets = (Total runs scored $\left(4^{*}\right.$ Fours $+6^{*}$ Sixes $\left.)\right) /$ Number of balls faced without boundary

6) Matches=Number of matches played

7) Runs= Total runs scored

8) BigScores $=$ Total number of half centuries and centuries

The above eight measures are typical T20 measures for a more detailed analysis of the performance of the batsmen. These 8 indices have been calculated for both T20 and IPL career data. Similarly, in order to define Bowling Capability eight indices are considered as follows.

1) Economy $=$ Total number of runs conceded / Total number of overs bowled

2) WicketTaker $=$ Total number of balls bowled / Total number of wickets taken

3) Consistent $=$ Total number of runs conceded $/$ Total number of wickets taken

4) BigWicketTaker $=$ Number of times four wickets or five wickets taken / Number of innings played

5) ShortPerformance $=$ (Number of wickets taken $-4 *$ Number of times four wickets $-5^{*}$ Number of times five wickets taken) / (Number of innings played -
Number of times four wickets or five wickets taken)

6) Matches $=$ Number of matches played

7) Overs $=$ Number of overs bowled

8) Wickets= Number of wickets taken

Indices are computed as above for each batsman and each bowler considering their latest T20 performance statistics available and their IPL performance up to season VIII for predicting the performance ranking for season 9. Similarly, the eight indices listed above are computed for each batsman and bowler considering their actual performance in IPL season 9 for calculating their actual performance ranking for season 9 .

When raw data is processed to get some predetermined features it is often the case that there is some strong correlation between some of the features and keeping all of them is unnecessary. One of them could actually suffice in such a case. Some of these features may not contribute significantly to the target performance index and actually act as noise. These features are to be eliminated so that only the significant ones are retained through features selection. The next task is to form a single index for ranking the relative performance of the batsmen and another index for ranking the bowlers. Some methodology might be used to determine the weightages for aggregation of selected features into a single formula while considering their relative importance. The "Caret" package in $\mathrm{R}$ provides features selection method based on the target variable and the assumed independent variables and is used for this purpose. In this work, the features selected form the independent variables or $\mathrm{X}$ vector and the MVPI forms the target variable for variable selection.

The two tasks are accomplished in this work as follows separately for batsmen and bowlers.

Step 1: Features that are more relevant to the target measure are selected for evaluating performance.

Step 2: The relative weightages of these features are also computed. This provides a weighted function as a comprehensive performance index.

Recursive Feature Elimination algorithm with Random Forests is used in order to select the important features and their relative importance. Random Forests algorithm is a state of the art procedure for various classification and regression tasks. Recursive Features Elimination using the Random Forests Algorithm works as follows. Each tree in constructed using a different bootstrap sample of data. Random forests also change how the classification or regression trees are constructed. Each node is split using the best among a subset of predictors randomly chosen at that node. This strategy has been shown to perform well and is robust against overfitting. It is very user-friendly. Only two parameters (the number of variables in the random subset at each node and the number of trees in the forest) are required to be chosen.

Recursive Feature Elimination (RFE) is used in this work for determining the relevant index for player ranking [15]. The algorithm fits the model to all the indices which are then ranked according to their importance to the model. The $\mathrm{N}$ top ranked indices are retained. Iteratively, the model is refit and performance is assessed. The value of $\mathrm{N}$ with the best performance is determined and the top $\mathrm{N}$ indices are used to fit the final model. 10-fold cross-validation is performed to ensure better robustness of results. A consensus ranking is 
used to finally determine the best indices to retain. More details of the procedure adopted are available in [15]

The selected features for calculating the Actual DPI and the Career DPI are shown in the tables 1 and 2 with their corresponding weightages obtained using Random Forests:

Table 1: Selected Features and their corresponding relative importance weightages for Actual DPI

\begin{tabular}{|l|l|l|l|}
\hline $\begin{array}{l}\text { Batting } \\
\text { Features for } \\
\text { Actual DPI }\end{array}$ & $\begin{array}{l}\text { Import } \\
\text { ance }\end{array}$ & $\begin{array}{l}\text { Bowling Features } \\
\text { for Actual DPI }\end{array}$ & $\begin{array}{l}\text { Impor } \\
\text { tance }\end{array}$ \\
\hline IPL_Runs & 0.457 & IPL_Wickets & 0.269 \\
\hline IPL_BigScore & 0.270 & IPL_Overs & 0.217 \\
\hline $\begin{array}{l}\text { IPL_ } \\
\text { Consistency }\end{array}$ & 0.210 & $\begin{array}{l}\text { IPL_Short } \\
\text { Performance }\end{array}$ & 0.195 \\
\hline IPL_Matches & 0.063 & IPL_Consistent & 0.167 \\
\hline & & IPL_WicketTaker & 0.152 \\
\hline
\end{tabular}

Table 2:Selected Features and their corresponding relative importance weightages for Career DPI

\begin{tabular}{|l|l|l|l|}
\hline $\begin{array}{l}\text { Batting Features } \\
\text { for Career DPI }\end{array}$ & $\begin{array}{l}\text { Impor } \\
\text { tance }\end{array}$ & $\begin{array}{l}\text { Bowling } \\
\text { Features for } \\
\text { Career DPI }\end{array}$ & $\begin{array}{l}\text { Impor } \\
\text { tance }\end{array}$ \\
\hline T20_Runs & 0.808 & T20_Wickets & 0.720 \\
\hline IPL_BigScore & 0.060 & T20_Matches & 0.117 \\
\hline T20_Consistency & 0.057 & T20_WicketTaker & 0.099 \\
\hline T20_BigScore & 0.038 & T20_Overs & 0.065 \\
\hline T20_Matches & 0.036 & & \\
\hline
\end{tabular}

The features and their relative importance selected by the recursive feature elimination process of Random Forests algorithm vary considerably for the computation of career DPI and actual DPI. For Career DPI the features considered are the career statistics of the players whereas Actual DPI is computed considering performance in IPL 9 alone. Therefore, although the top five features reflect almost the same attributes in both cases the data from which they are computed is different and so are the relative weightages. The indices for Actual DPI give lesser importance to total number of runs and more weightage to big scores and Consistency for batsmen. Similarly, for bowlers, the index has more factors than just wickets and is more comprehensive reflecting more aspects of the performance.

An aggregate function of these indices is required to calculate the actual Ranking of a batsman or a bowler. Since the ranges of absolute values of the indices are widely different, these are first normalized to lie within a range on 0 to 1 . This is done as follows.

- For each index, the list is sorted in descending order of preference i.e. best performer first i.e. the best performer has rank 1 with others following.

- Points for that particular index are calculated as

Points $=($ No of Players - Rank according to that particular feature)/ No of players

It is clear that the maximum value for Points is 1 . That will be for the player whose rank is 1 in that feature.

The formulas for calculating the DPI's are as follows:

Actual Batting DPI $=(0.457 *$ IPL_Runs Points $)+(0.270 *$ IPL_BigScore Points $)+(0.210 *$ IPL_Consistency $)+(0.063 *$ IPL Match Points)
Actual Bowling DPI $=(0.269 *$ IPL_Wickets $)+(0.217 *$ IPL_Overs $)+\left(0.195^{*}\right.$ IPL_ShortPerformance $)+$ $(0.167 *$ IPL_Consistent $)+(0.152 *$ IPL_WicketTaker $)$

Career Batting DPI $=\left(0.808^{*}\right.$ T20_Runs $)+$ $(0.060 *$ IPL_BigScore $)+(0.057 *$ T20_Consistency $)+(0.038 *$ T20_BigScore $)+(0.036 *$ T20_Matches $)$

Career Bowling DPI $=(0.720 *$ T20_Wickets $)+$ $(0.117 *$ T20_Matches $)+(0.099 *$ T20_WicketTaker $)+$ $(0.065 *$ T20_Overs $)$

The Career DPIs are used for predicting the performance in IPL Season 9 whereas the Actual DPI is the index of actual performance in IPL Season 9.

The Selling Price (SP) is the actual price paid by the franchisee in acquiring that player. The difference represents the expectations of stellar performance from that player. The higher the difference, the greater the expectations. These expectations are built around many factors including past performance (career DPI), current form, player's popularity and charisma, preference of a particular franchisee according to its game plan etc. Therefore, it is not necessary that a player with higher career DPI also have a higher selling price.

Tables 3 to 6 show the top 5 players according to career DPI and actual DPI

Table 3:Top 5 Batsmen in season 9 according to actual DPI

\begin{tabular}{|l|l|l|l|l|l|}
\hline Player & Team & $\begin{array}{l}\text { Actual } \\
\text { DPI }\end{array}$ & $\begin{array}{l}\text { Career } \\
\text { DPI }\end{array}$ & $\begin{array}{l}\text { Selling } \\
\text { Price } \\
\text { (in } \\
\text { crores) }\end{array}$ & MVPI \\
\hline V Kohli & RCB & 0.996 & 0.844 & 15 & 4076.1 \\
\hline D Warner & SRH & 0.983 & 0.839 & 5.5 & 2915.5 \\
\hline de Villiers & RCB & 0.967 & 0.839 & 9.5 & 2378.3 \\
\hline G Gambhir & KKR & 0.929 & 0.623 & 11.04 & 1103.4 \\
\hline R Sharma & MI & 0.925 & 0.813 & 11.5 & 1255.9 \\
\hline
\end{tabular}

Table 4: Top 5 Bowlers in season 9 according to Actual DPI

\begin{tabular}{|l|l|l|l|l|l|}
\hline Player & Team & $\begin{array}{l}\text { Actual } \\
\text { DPI }\end{array}$ & $\begin{array}{l}\text { Career } \\
\text { DPI }\end{array}$ & $\begin{array}{l}\text { Selling } \\
\text { Price } \\
\text { (in } \\
\text { crores) }\end{array}$ & MVPI \\
\hline Y Chahal & RCB & 0.946 & 0.688 & 0.1 & 62.35 \\
\hline B Kumar & SRH & 0.931 & 0.669 & 4.25 & 68.63 \\
\hline D Kulkarni & GLR & 0.896 & 0.718 & 2 & 55.37 \\
\hline S Watson & RCB & 0.896 & 0.547 & 9.5 & 49.14 \\
\hline $\begin{array}{l}\text { M } \\
\text { McCleneghan }\end{array}$ & MI & 0.859 & 0.921 & 0.3 & 42.02 \\
\hline
\end{tabular}

Table 5: Top 5 Batsman according to the Career DPI

\begin{tabular}{|l|l|l|l|l|l|}
\hline Player & Team & $\begin{array}{l}\text { Career } \\
\text { DPI }\end{array}$ & $\begin{array}{l}\text { Actual } \\
\text { DPI }\end{array}$ & $\begin{array}{l}\text { Actual } \\
\text { DPI }-\end{array}$ & $\begin{array}{l}\text { Selling } \\
\text { Career } \\
\text { DPI }\end{array}$ \\
$\begin{array}{l}\text { (in } \\
\text { crores) }\end{array}$ \\
\hline C Gayle & RCB & 0.969 & 0.608 & -0.360 & 8.4 \\
\hline D Miller & KXIP & 0.935 & 0.402 & -0.533 & 5 \\
\hline $\begin{array}{l}\text { MS } \\
\text { Dhoni }\end{array}$ & RPS & 0.913 & 0.761 & -0.152 & 12.5 \\
\hline S Marsh & KXIP & 0.912 & 0.529 & -0.384 & 2.2 \\
\hline $\begin{array}{l}\text { K } \\
\text { Peterson }\end{array}$ & RPS & 0.884 & 0.352 & -0.532 & 3.5 \\
\hline
\end{tabular}


Table 6: Top 5 Bowlers according to Career DPI

\begin{tabular}{|l|l|l|l|l|l|}
\hline Player & Team & $\begin{array}{l}\text { Career } \\
\text { DPI }\end{array}$ & $\begin{array}{l}\text { Actual } \\
\text { DPI }\end{array}$ & $\begin{array}{l}\text { Actual } \\
\text { DPI - } \\
\text { Career } \\
\text { DPI }\end{array}$ & $\begin{array}{l}\text { Selling } \\
\text { Price } \\
\text { (in } \\
\text { crores) }\end{array}$ \\
\hline $\begin{array}{l}\text { M } \\
\text { McCleneghan }\end{array}$ & MI & 0.921 & 0.859 & -0.062 & 0.3 \\
\hline I Tahir & DD & 0.901 & 0.649 & -0.256 & 1 \\
\hline SA Hasan & KKR & 0.896 & 0.437 & -0.458 & 3.8 \\
\hline S Narine & KKR & 0.894 & 0.723 & -0.171 & 2.4 \\
\hline S Sharma & KXIP & 0.892 & 0.841 & -0.051 & 0.85 \\
\hline
\end{tabular}

Some observations from Tables 3 to 6 are noteworthy as follows.

(i) The Selling Price is not commensurate with Career DPI.

(ii) The top batsmen appear to have much higher selling price than the top bowlers reflecting the fact that T20 and especially IPL is very much the batsmen's game at least from the point of view of prices the players command. The average price for top 5 batsmen according to career DPI is 6.32 crores whereas it is only 1.67 crores for top 5 bowlers. The franchises seem to build their strategies around batsmen more than bowlers.

(iii) None of the top 5 batsmen according to career DPI is among the top 5 according to actual performance in IPL 9.

(iv) Only one bowler i.e. Mitchell McCleneghan appears in both Tables 4 and 6 .

(v) Large difference between Career DPI and Actual DPI shows that the player either played much above or much below his potential depending on which DPI is higher.

(vi) All the entries in the column Actual DPI - Career DPI are negative. This indicates that all the five batsmen as well as top five bowlers performed below expectations. Worst were David Miller and Kevin Peterson for whom this difference is greater than 0.5 implying that more than $50 \%$ of the players who were expected to perform worse than them actually turned in better performances! And these players are some of the more expensive ones.

This motivates the need for a study of price performance of IPL players and creation of better indices that reflect comprehensively both price and performance. An attempt is made in the next section to fill this gap.

\section{MAYO INDEX CALCULATION}

The best DPI that a player can have is 1 . The Career DPI reflects the performance of the player over his entire career. In order to see how much improvement he has made in his DPI, Actual DPI is computed solely on performance in IPL 9.

The MAYO Index can be defined as:

MAYO Index $=($ Actual DPI - Career DPI $) /(1-$ Career DPI)

This is dubbed as Most Amazing Yield Observation (MAYO) index as it throws up insights regarding price and performance of players in IPL 9 that are otherwise not available. It is called
Yield as it shows value for money. MAYO Index cannot exceed 1.

The rationale for this choice of index is as follows. The MAYO index would be 1 or close to 1 for a player whose Actual DPI is 1 or close to 1 implying that his performance was best among the lot. If a player has a Career DPI close to 1 and Actual DPI is lesser, say 0.8, it means that the player played much below potential. This is shown in Tables 5 and 6 for the top 5 batsmen and top 5 bowlers according to Career DPI.

The quantity (Actual DPI - Career DPI) reflects the performance improvement of the player in IPL 9 over the expected performance. Since the maximum value of Actual DPI can be 1 the MAYO index reflects the extent to which a player has given an improved performance as a fraction of maximum possible improvement in performance when the index is positive. This is fairer than the other indices because if a player's Career DPI is very high already then the scope for further improvement to be reflected in the difference between Career DPI and Actual DPI is very small in absolute terms. But the fraction might still be a relatively large value showing improved performance. When the index is negative it reflects how much deterioration in performance has taken place.

Based on the MAYO Index the players are classified into three classes, namely A, B and C. According to MAYO Index the top $1 / 3$ players are classified into class $A$, the next $1 / 3$ players into class B and last $1 / 3$ into class $C$.

Another classification of players has been done based on their selling price. If players are sorted in the descending order of selling price then top $1 / 3$ are classified into class $A$, next $1 / 3$ are classified into class $\mathrm{B}$ and the next $1 / 3$ are classified into type $\mathrm{C}$.

Table 7: Classes and the respective ranges of MAYO index and selling price

\begin{tabular}{|c|c|c|c|c|}
\hline Class & $\begin{array}{l}\text { Batting } \\
\text { MAYO }\end{array}$ & $\begin{array}{l}\text { Selling } \\
\text { Price for } \\
\text { Batsmen } \\
\text { (in crores) }\end{array}$ & $\begin{array}{l}\text { Bowling } \\
\text { MAYO }\end{array}$ & $\begin{array}{l}\text { Selling } \\
\text { Price for } \\
\text { bowlers } \\
\text { (in crores) }\end{array}$ \\
\hline $\mathrm{A}$ & $\begin{array}{ll}0.98 & - \\
0.31 & \end{array}$ & $15-4.25$ & $\begin{array}{ll}0.83 & - \\
0.24 & \end{array}$ & $12.5-3.5$ \\
\hline B & $0.31-0$ & $4.25-1.6$ & $\begin{array}{lll}0.24 & - & - \\
0.30 & & \end{array}$ & $3.5-0.8$ \\
\hline $\mathrm{C}$ & $0--11.50$ & $1.6-0.1$ & $\begin{array}{l}-0.30-\quad- \\
4.39\end{array}$ & $0.8-0.1$ \\
\hline
\end{tabular}

Once both the classifications have been done then two classifications are combined to depict the combined performance and Price. The combined classes and their definitions are as given in Table 8 .

Table 8: Classes and their definitions

\begin{tabular}{|l|l|}
\hline Class & Definition \\
\hline AA & $\begin{array}{l}\text { Performance of class A and Price also of class A } \\
\text { (Performed according to expectations) }\end{array}$ \\
\hline AB & $\begin{array}{l}\text { Performance of class A but Price of class B } \\
\text { (Performed above expectations) }\end{array}$ \\
\hline AC & $\begin{array}{l}\text { Performance of class A but Price of class C } \\
\text { (Performed much beyond expectations) }\end{array}$ \\
\hline BA & $\begin{array}{l}\text { Performance of class B but price of class A } \\
\text { (Performed below expectations ) }\end{array}$ \\
\hline BB & $\begin{array}{l}\text { Performance of class B and Price of class B } \\
\text { (Performed according to expectations) }\end{array}$ \\
\hline
\end{tabular}




\begin{tabular}{|l|l|}
\hline BC & $\begin{array}{l}\text { Performance of class B but Price of class } \\
\text { C(Performed above expectations) }\end{array}$ \\
\hline CA & $\begin{array}{l}\text { Performance of class C but Price of class A } \\
\text { (Performed much below expectations) }\end{array}$ \\
\hline CB & $\begin{array}{l}\text { Performance of class C but Price of class B ( } \\
\text { Performed below expectations) }\end{array}$ \\
\hline CC & $\begin{array}{l}\text { Performance of class C and price of class C } \\
\text { (Performed according to expectations) }\end{array}$ \\
\hline
\end{tabular}

The batsmen and bowlers are classified according to the classes mentioned in Table 8 and listed in the descending order of their actual DPI i.e. best performer first and the results are given in Tables 9 and 10 .

\section{Table 9: Classification of Batsmen}

\begin{tabular}{|c|c|}
\hline $\begin{array}{l}\text { Class } \\
\text { (Count) }\end{array}$ & Players \\
\hline $\begin{array}{l}\text { AA } \\
\text { (9) }\end{array}$ & $\begin{array}{l}\text { Virat Kohli, David Warner, Gautam Gambhir, } \\
\text { AB de Villiers, Shikhar Dhawan, Ajinkya } \\
\text { Rahane, Rohit Sharma, Ambati Rayudu, Chris } \\
\text { Morris }\end{array}$ \\
\hline $\begin{array}{l}\text { AB } \\
\text { (11) }\end{array}$ & $\begin{array}{l}\text { Murali Vijay, Karun Nair, Krunal Pandya, } \\
\text { Yusuf Pathan, Rishabh Pant, Quinton De Kock, } \\
\text { Dinesh Karthik, Sanju Samson, Manish Pandey, } \\
\text { Deepak Hooda, Dwayne Smith }\end{array}$ \\
\hline $\begin{array}{l}\text { AC } \\
\text { (7) }\end{array}$ & $\begin{array}{l}\text { Lokesh Rahul, Marcus Stoinis, Nitish Rana, } \\
\text { Aaron Finch, Suryakumar Yadav, Sarfaraz } \\
\text { Khan, AxarPatel }\end{array}$ \\
\hline $\begin{array}{l}\text { BA } \\
\text { (8) }\end{array}$ & $\begin{array}{l}\text { Robin Uthappa, Harbhajan Singh, Ravinder } \\
\text { Jadeja, R.Ashwin, Bhuvneshwar Kumar, Glenn } \\
\text { Maxwell, Mohit Sharma, Steve Smith }\end{array}$ \\
\hline $\begin{array}{l}\text { BB } \\
\text { (7) }\end{array}$ & $\begin{array}{l}\text { Jos Butler, Wriddhiman Saha, Carlos } \\
\text { Braithwite, Parthiv Patel, Shakib al Hasan, Faf } \\
\text { DuPlesis, Praveen Kumar }\end{array}$ \\
\hline $\begin{array}{l}\text { BC } \\
(12)\end{array}$ & $\begin{array}{l}\text { Travis Head, Sachin Baby, Bipul Sharma, Sam } \\
\text { Billings, Gurkeerat Singh Mann, Usman } \\
\text { Khwaja, Thisara Perera, Iqbal Abdulla, Mitchell } \\
\text { McCleneghan, Ishan Kishan, HashimAmla, } \\
\text { Ashish Reddy }\end{array}$ \\
\hline $\begin{array}{l}\text { CA } \\
\text { (10) }\end{array}$ & $\begin{array}{l}\text { Yuvraj Singh, Piyush Chawla, James Faulkner, } \\
\text { Brendon McCullum, Suresh Raina, Kieron } \\
\text { Pollard, MS Dhoni, Shane Watson, David } \\
\text { Miller, Chris Gayle }\end{array}$ \\
\hline $\begin{array}{l}\text { CB } \\
\text { (9) }\end{array}$ & $\begin{array}{l}\text { Stuart Binny, Karan Sharma, Manan Vohra, } \\
\text { Mayank Aggarwal, KedarJadhav, Dwayne } \\
\text { Bravo, JP Duminy, Shaun Marsh, Kevin } \\
\text { Peterson }\end{array}$ \\
\hline $\begin{array}{l}\mathbf{C C} \\
(8)\end{array}$ & $\begin{array}{l}\text { Ben Cutting, Eoin Morgan, Andre Russell, } \\
\text { Moises Henriques, Saurabh Tiwary, Kane } \\
\text { Williamson, Martin Guptil, Chris Lynn }\end{array}$ \\
\hline
\end{tabular}

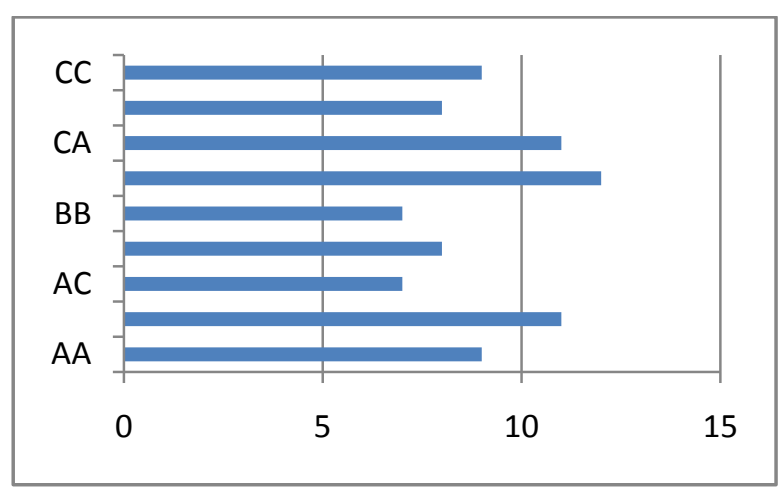

Fig 1: Number of batsmen in each class

Table 10: Classification of Bowlers

\begin{tabular}{|c|c|}
\hline $\begin{array}{l}\text { Class } \\
\text { (Count) }\end{array}$ & Players \\
\hline $\begin{array}{l}\mathbf{A A} \\
(7)\end{array}$ & $\begin{array}{l}\text { Bhuvneshwar Kumar, Shane Watson, M } \\
\text { Ashwin, Carlos Braithwite, Praveen Kumar, } \\
\text { Deepak Hooda, Piyush Chawla }\end{array}$ \\
\hline $\begin{array}{l}\mathbf{A B} \\
\text { (11) }\end{array}$ & $\begin{array}{l}\text { Barinder Sran, Mustafizur Rehman, Jasprit } \\
\text { Bumrah, Dhawal Kulkarni, Chris Jordan, } \\
\text { Umesh Yadav, Kane Richardson, Dwayne } \\
\text { Smith, Bipul Sharma, KC Cariappa, Tim } \\
\text { Southee }\end{array}$ \\
\hline $\begin{array}{l}\mathrm{AC} \\
(12)\end{array}$ & $\begin{array}{l}\text { Yuzvendra Chahal, Adam Zampa, Andren } \\
\text { Russell, Marcus Stoinis, Ashok Dinda, Shivil } \\
\text { Kaushik, Sreenath Arvind, Ben Cutting, Tabrez } \\
\text { Shamsi, Kuldeep Yadav, Pradeep Sahu, Scott } \\
\text { Boland }\end{array}$ \\
\hline $\begin{array}{l}\text { BA } \\
\text { (12) }\end{array}$ & $\begin{array}{l}\text { Ravinder Jadeja, Mitchel Marsh, Chris Gayle, } \\
\text { Chris Morris, Zaheer Khan, Ishant Sharma, } \\
\text { Dwayne Bravo, Glenn Maxwell, Suresh Raina, } \\
\text { Yusuf Pathan, R.Ashwin, Ashish Nehra }\end{array}$ \\
\hline $\begin{array}{l}\text { BB } \\
\text { (11) }\end{array}$ & $\begin{array}{l}\text { Rishi Dhawan, Moises Henriques, Kyle Abott, } \\
\text { JP Duminy, Thisara Perera, Parvez Rasool, } \\
\text { Morne Morkel, Krunal Pandya, Shahbaz } \\
\text { Nadeem, Vinay Kumar, Harbhajan Singh }\end{array}$ \\
\hline $\begin{array}{l}\text { BC } \\
\text { (7) }\end{array}$ & $\begin{array}{l}\text { Axar Patel, R.Sathish, Hardik Pandya, Jason } \\
\text { Holder, Deepak Chahar, Rajat Bhatia, Iqbal } \\
\text { Abdulla }\end{array}$ \\
\hline $\begin{array}{l}\text { CA } \\
(11)\end{array}$ & $\begin{array}{l}\text { Mohammad Shami, Pawan Negi, Mohit } \\
\text { Sharma, Amit Mishra, Yuvraj Singh, Karan } \\
\text { Sharma, Kieron Pollard, James Faulkner, } \\
\text { Mitchell Johnson, Nathan Coulter Nile, Shakib } \\
\text { Al Hasan }\end{array}$ \\
\hline $\begin{array}{l}\text { CB } \\
\text { (8) }\end{array}$ & $\begin{array}{l}\text { Sandeep Sharma, Ankit Rajpoot, Stuart Binny, } \\
\text { Varun Aaron, John Hastings, Irfan Pathan, } \\
\text { Sunil Narine, Imran Tahir }\end{array}$ \\
\hline $\begin{array}{l}\text { CC } \\
(9)\end{array}$ & $\begin{array}{l}\text { Jayant Yadav, Pravin Tambe, Ankit Sharma, } \\
\text { Albie Morkel, ShadabJakati, Mitchel } \\
\text { McCleneghan, Brad Hogg, Harshal Patel, } \\
\text { AnureetSingh }\end{array}$ \\
\hline
\end{tabular}




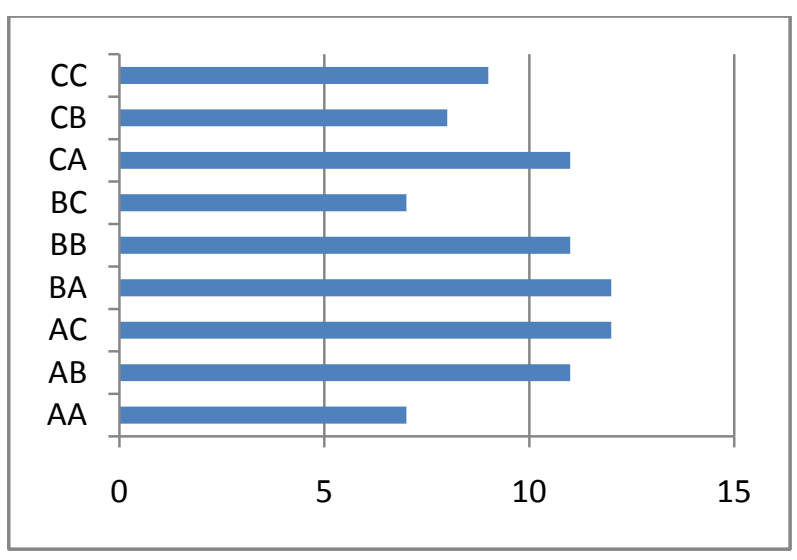

Fig 2: Number of bowlers in each class

Some observations from Tables 9 and 10 are as follows.

(i) Class AA batsmen and bowlers are the star players who performed according to expectations and the big names there indicate this.

(ii) The list of Class CA batsmen contains some very big names in T20 like Gayle, Dhoni, McCullum and Raina who had a bad IPL 9 season they were expected to do very well. Simlarly, class CA bowlers are Shami, Pollard, Coulter Nile, Mitchell Johnson etc.

(iii) The important players to watch for in future are class AC players. These are players who excelled themselves and performed much beyond expectations. Some of them are already knocking on the doors of the national team whereas others have made it. These include Lokesh Rahul, Marcus Stoinis, Nitish Rana, Suryakumar Yadav, Sarfaraz Khan, Axar Patel among batsmen and Yuzvendra Chahal, Adam Zampa, Andre Russell, Marcus Stoinis, Ashok Dinda, Shivil Kaushik among bowlers.

(iv) Class $\mathrm{CC}$ players still have to prove that they belong to big leagues but may as well do so in future.

\section{RESULTS AND DISCUSSIONS}

Top ten and bottom ten players according to MAYO Index (MI) are given in Tables 11 and 12.

Table 11: Top ten and Bottom ten batsmen according to MAYO Index (MI)

\begin{tabular}{|l|l|l|l|l|l|}
\hline Top Ten & Team & MI & $\begin{array}{l}\text { Bottom } \\
\text { Ten }\end{array}$ & Team & MI \\
\hline $\begin{array}{l}\text { Virat } \\
\text { Kohli }\end{array}$ & RCB & 0.974 & C Gayle & RCB & -11.501 \\
\hline $\begin{array}{l}\text { David } \\
\text { Warner }\end{array}$ & SRH & 0.895 & $\begin{array}{l}\text { David } \\
\text { Miller }\end{array}$ & KXIP & -8.160 \\
\hline $\begin{array}{l}\text { Gautam } \\
\text { Gambhir }\end{array}$ & KKR & 0.812 & $\begin{array}{l}\text { Kevin } \\
\text { Peterson }\end{array}$ & RPS & -4.607 \\
\hline $\begin{array}{l}\text { Lokesh } \\
\text { Rahul }\end{array}$ & RCB & 0.807 & $\begin{array}{l}\text { Shaun } \\
\text { Marsh }\end{array}$ & KXIP & -4.373 \\
\hline $\begin{array}{l}\text { de } \\
\text { Villiers }\end{array}$ & RCB & 0.794 & $\begin{array}{l}\text { Shane } \\
\text { Watson }\end{array}$ & RCB & -2.148 \\
\hline $\begin{array}{l}\text { Murali } \\
\text { Vijay }\end{array}$ & KXIP & 0.764 & $\begin{array}{l}\text { JP } \\
\text { Duminy }\end{array}$ & DD & -1.974 \\
\hline $\begin{array}{l}\text { Shikhar } \\
\text { Dhawan }\end{array}$ & SRH & 0.747 & $\begin{array}{l}\text { MS } \\
\text { Dhoni }\end{array}$ & RPS & -1.743 \\
\hline Ajinkhya & RPS & 0.745 & Chris & KKR & -1.155 \\
\hline
\end{tabular}

\begin{tabular}{|l|l|l|l|l|l|}
\hline Rahane & & & Lynn & & \\
\hline $\begin{array}{l}\text { Karun } \\
\text { Nair }\end{array}$ & DD & 0.726 & $\begin{array}{l}\text { Martin } \\
\text { Guptil }\end{array}$ & MI & -0.886 \\
\hline $\begin{array}{l}\text { Krunal } \\
\text { Pandya }\end{array}$ & MI & 0.710 & $\begin{array}{l}\text { Kieron } \\
\text { Pollard }\end{array}$ & MI & -0.795 \\
\hline
\end{tabular}

Table 12: Top ten and Bottom ten bowlers according to MAYO Index

\begin{tabular}{|l|l|l|l|l|l|}
\hline $\begin{array}{l}\text { Top } \\
\text { Ten }\end{array}$ & Team & MI & $\begin{array}{l}\text { Bottom } \\
\text { Ten }\end{array}$ & Team & MI \\
\hline $\begin{array}{l}\text { Y } \\
\text { Chahal }\end{array}$ & RCB & 0.826 & $\begin{array}{l}\text { Shakib } \\
\text { Hasan }\end{array}$ & KKR & -4.393 \\
\hline $\begin{array}{l}\text { Adam } \\
\text { Zampa }\end{array}$ & RPS & 0.793 & $\begin{array}{l}\text { Coulter } \\
\text { Nile }\end{array}$ & DD & -3.047 \\
\hline $\begin{array}{l}\text { B } \\
\text { Kumar }\end{array}$ & SRH & 0.793 & $\begin{array}{l}\text { Imran } \\
\text { Tahir }\end{array}$ & DD & -2.590 \\
\hline $\begin{array}{l}\text { Barinder } \\
\text { Sran }\end{array}$ & SRH & 0.787 & $\begin{array}{l}\text { Mitchell } \\
\text { Johnson }\end{array}$ & KXIP & -1.875 \\
\hline $\begin{array}{l}\text { Shane } \\
\text { Watson }\end{array}$ & RCB & 0.770 & $\begin{array}{l}\text { James } \\
\text { Faulkner }\end{array}$ & GLR & -1.836 \\
\hline $\begin{array}{l}\text { Andre } \\
\text { Russell }\end{array}$ & KKR & 0.745 & $\begin{array}{l}\text { Sunil } \\
\text { Narine }\end{array}$ & KKR & -1.618 \\
\hline $\begin{array}{l}\text { M } \\
\text { Rehman }\end{array}$ & SRH & 0.655 & $\begin{array}{l}\text { Kieron } \\
\text { Pollard }\end{array}$ & MI & -1.615 \\
\hline $\begin{array}{l}\text { J } \\
\text { Bumrah }\end{array}$ & MI & 0.650 & $\begin{array}{l}\text { Karn } \\
\text { Sharma }\end{array}$ & SRH & -1.486 \\
\hline $\begin{array}{l}\text { M } \\
\text { Stoinis }\end{array}$ & KXIP & 0.637 & $\begin{array}{l}\text { Yuvraj } \\
\text { Singh }\end{array}$ & SRH & -1.467 \\
\hline $\begin{array}{l}\text { D } \\
\text { Kulkarni }\end{array}$ & GLR & 0.630 & $\begin{array}{l}\text { Anureet } \\
\text { Singh }\end{array}$ & KXIP & -1.214 \\
\hline
\end{tabular}

The following can be observed from tables 11 and 12 .

(i) Four out of top 5 batsmen and four out of top 5 bowlers are from the teams which played the finals i.e. SRH and RCB showing that the Mayo index indeed reflects the actual situation. Further, the teams have to perform on all fronts to make it to the finals.

(ii) Conversely, from the finalists teams only two players are in bottom 10 batsmen and bowlers.

(iii) Table 11 shows that only two overseas players are there in top ten batsmen, the other eight being Indian players.

(iv) From Table 11, there is only one Indian batsman among bottom 10 batsmen and rest all are overseas players.

(v) Similarly, from Table 12, there are 5 Indian bowlers in top 10.

(vi) Further, from Table 12 again, there are only 3 Indian bowlers in bottom ten bowlers.

In order to do deeper analysis team-wise classification has been done and the results are shown in the Tables 13 and 14 .

Table 13: Country-wise classification of Batsmen

\begin{tabular}{|l|l|l|l|l|l|l|l|l|l|}
\hline Country & \multicolumn{10}{|c|}{ Class } \\
\hline & $\mathbf{A}$ & $\mathbf{A}$ & $\mathbf{A}$ & $\mathbf{B}$ & $\mathbf{B}$ & $\mathbf{B}$ & $\mathbf{C}$ & $\mathbf{C}$ & $\mathbf{C}$ \\
& $\mathbf{A}$ & $\mathbf{B}$ & $\mathbf{C}$ & $\mathbf{A}$ & $\mathbf{B}$ & $\mathbf{C}$ & $\mathbf{A}$ & $\mathbf{B}$ & $\mathbf{C}$ \\
\hline Australia & 1 & 0 & 2 & 2 & 0 & 2 & 2 & 1 & 3 \\
\hline $\begin{array}{l}\text { Banglad } \\
\text { esh }\end{array}$ & 0 & 0 & 0 & 0 & 1 & 0 & 0 & 0 & 0 \\
\hline England & 0 & 0 & 0 & 0 & 1 & 1 & 0 & 1 & 1 \\
\hline India & $\mathbf{6}$ & $\mathbf{9}$ & $\mathbf{5}$ & $\mathbf{6}$ & $\mathbf{3}$ & $\mathbf{6}$ & $\mathbf{4}$ & $\mathbf{5}$ & $\mathbf{1}$ \\
\hline New & 0 & 0 & 0 & 0 & 0 & 1 & 1 & 0 & 2 \\
\hline
\end{tabular}




\begin{tabular}{|l|l|l|l|l|l|l|l|l|l|}
\hline Zealand & & & & & & & & & \\
\hline $\begin{array}{l}\text { South } \\
\text { Africa }\end{array}$ & 2 & 1 & 0 & 0 & 1 & 1 & 1 & 1 & 0 \\
\hline $\begin{array}{l}\text { Sri } \\
\text { Lanka }\end{array}$ & 0 & 0 & 0 & 0 & 0 & 1 & 0 & 0 & 0 \\
\hline $\begin{array}{l}\text { West } \\
\text { Indies }\end{array}$ & 0 & 1 & 0 & 0 & 1 & 0 & 2 & 1 & 1 \\
\hline
\end{tabular}

It can be clearly seen from the table 13 that out of 27 Class A batsmen 20 are Indian and in the C class batsmen the overseas players from Australia and West Indies are in majority. Youngsters from India are doing well in IPL because based on their IPL performance they can be selected into National team. However, the same cannot be said about many overseas batsmen. One possible reason can be that overseas batsmen are not able perform well on the Indian pitches which are different from what they are more used.

Table 14: Country-wise classification of Bowlers

\begin{tabular}{|l|l|l|l|l|l|l|l|l|l|}
\hline Country & \multicolumn{10}{|c|}{ Class } \\
\hline & $\mathbf{A}$ & $\mathbf{A}$ & $\mathbf{A}$ & $\mathbf{B}$ & $\mathbf{B}$ & $\mathbf{B}$ & $\mathbf{C}$ & $\mathbf{C}$ & $\mathbf{C}$ \\
& $\mathbf{A}$ & $\mathbf{B}$ & $\mathbf{C}$ & $\mathbf{A}$ & $\mathbf{B}$ & $\mathbf{C}$ & $\mathbf{A}$ & $\mathbf{B}$ & $\mathbf{C}$ \\
\hline Australia & 1 & 1 & 4 & 2 & 1 & 0 & 3 & 1 & 1 \\
\hline $\begin{array}{l}\text { Banglade } \\
\text { sh }\end{array}$ & 0 & 1 & 0 & 0 & 0 & 0 & 1 & 0 & 0 \\
\hline England & 0 & 1 & 0 & 0 & 0 & 0 & 0 & 0 & 0 \\
\hline India & $\mathbf{5}$ & $\mathbf{6}$ & $\mathbf{6}$ & $\mathbf{7}$ & $\mathbf{6}$ & $\mathbf{6}$ & $\mathbf{6}$ & $\mathbf{5}$ & $\mathbf{7}$ \\
\hline $\begin{array}{l}\text { New } \\
\text { Zealand }\end{array}$ & 0 & 1 & 0 & 0 & 0 & 0 & 0 & 0 & 1 \\
\hline $\begin{array}{l}\text { South } \\
\text { Africa }\end{array}$ & 0 & 0 & 1 & 1 & 3 & 0 & 0 & 1 & 1 \\
\hline Sri Lanka & 0 & 0 & 0 & 0 & 1 & 0 & 0 & 0 & 0 \\
\hline $\begin{array}{l}\text { West } \\
\text { Indies }\end{array}$ & 1 & 1 & 1 & 2 & 0 & 1 & 1 & 1 & 0 \\
\hline
\end{tabular}

It can be seen from the table 14 that Indian bowlers have mixed performance in all the three classes. The interesting facts are Australian and West Indian bowlers have performed well. This is interesting because the batsmen from these countries didn't perform well.

Table 15: Team-wise classification of Batsmen

\begin{tabular}{|l|l|l|l|l|l|l|l|l|l|}
\hline $\begin{array}{l}\text { Tea } \\
\text { m }\end{array}$ & \multicolumn{9}{|c|}{ Class } \\
\hline & A & A & A & B & B & B & C & C & C \\
& A & B & C & A & B & C & A & B & C \\
\hline DD & $\mathbf{1}$ & 4 & 0 & 0 & 1 & $\mathbf{1}$ & 0 & 2 & 0 \\
\hline GLR & 0 & 2 & 1 & 1 & 1 & 1 & 3 & 1 & 0 \\
\hline KKR & 1 & 2 & 1 & 1 & 1 & 0 & 1 & 0 & 2 \\
\hline KXIP & 0 & 1 & 2 & 2 & 1 & 2 & 1 & 2 & 0 \\
\hline MI & 2 & 1 & 1 & 1 & 2 & 1 & 1 & 0 & 1 \\
\hline RCB & 2 & 0 & 2 & 0 & 0 & 3 & 2 & 2 & 0 \\
\hline RPS & 1 & 0 & 0 & 2 & 1 & 2 & 1 & 1 & 1 \\
\hline SRH & 2 & 1 & 0 & 1 & 0 & 2 & 1 & 1 & 4 \\
\hline
\end{tabular}

It can be clearly seen from the table 15 that team Delhi Daredevils's(DD) batsmen have performed well although they could not go all the way in the tournament. Youngsters like Chris Morris, Quinton De Kock, Karun Nair, Sanju Samson, Rishabh Pant were among the talented Delhi team who performed according to class $\mathrm{A}$. What probably cost them was that they had only one Class A bowler as shown in table 16 .
Table 16: Team-wise classification of Bowlers

\begin{tabular}{|l|c|l|l|l|l|l|l|l|l|}
\hline Team & \multicolumn{10}{|c|}{ Class } \\
\hline & $\mathbf{A}$ & $\mathbf{A}$ & $\mathbf{A}$ & $\mathbf{B}$ & $\mathbf{B}$ & $\mathbf{B}$ & $\mathbf{C}$ & $\mathbf{A}$ & $\mathbf{B}$ \\
& $\mathbf{A}$ & $\mathbf{B}$ & $\mathbf{C}$ & $\mathbf{A}$ & $\mathbf{B}$ & $\mathbf{C}$ & $\mathbf{C}$ & $\mathbf{C}$ & $\mathbf{C}$ \\
\hline DD & 1 & 0 & 0 & 2 & 2 & 0 & 4 & 1 & 0 \\
\hline GLR & 1 & 2 & 1 & 3 & 0 & 0 & 1 & 0 & 2 \\
\hline KKR & 1 & 1 & 2 & 1 & 1 & 2 & 1 & 3 & 1 \\
\hline KXIP & 0 & 1 & 2 & 1 & 2 & 1 & 2 & 1 & 1 \\
\hline MI & 0 & 2 & 0 & 0 & 3 & 1 & 1 & 0 & 1 \\
\hline RCB & $\mathbf{1}$ & $\mathbf{2}$ & $\mathbf{3}$ & $\mathbf{1}$ & $\mathbf{1}$ & $\mathbf{1}$ & $\mathbf{0}$ & $\mathbf{2}$ & $\mathbf{1}$ \\
\hline RPS & 1 & 0 & 3 & 3 & 1 & 2 & 0 & 1 & 3 \\
\hline SRH & $\mathbf{2}$ & $\mathbf{3}$ & $\mathbf{1}$ & $\mathbf{1}$ & $\mathbf{1}$ & $\mathbf{0}$ & $\mathbf{2}$ & $\mathbf{0}$ & $\mathbf{0}$ \\
\hline
\end{tabular}

Two teams who played the IPL 9 final i.e. RCB and SRH, they clearly have better bowlers than any other team as they have more Class A bowlers according to the table 16 . Yazuvendra Chahal, Shane Watson, Chris Jordan, Sreenath Arvind, Kane Richardson, Tabrez Shamsi were RCB's A class bowlers and Bhuvneshwar Kumar, Barinder Sran, Mustafizur Rehman, Ben Cutting, Bipul Sharma, Deepak Hooda were SRH's class A bowlers. This shows the importance of bowlers in IPL which is not too often appreciated. T20 is treated more like a Batsmen's game and they are paid more than the bowlers but facts clearly show that bowlers also make a difference.

\section{CONCLUSIONS}

Analytics has come a long way in various domains like business and health care. In this paper, techniques from machine learning as adapted to perform and insightful analysis of the price and performances in IPL season 9. A new index called the Most Amazing Yield Observation (MAYO) index is defined and, true to its name, it does offer amazing in-depth insights into the performance of the players vis-a-viz the price that the franchisees paid to acquire them in their team. The methodology and the results are of interest not only to cricket enthusiasts but also for the managers and administrators in this big money game which is not just a game in India.

However, further study is necessary to some up with a more realistic index. The MAYO index currently considers purely performance aspects and matches them with the price. However, IPL is not only a competitive tournament. It would not exist if the crowds do not turn up to see the matches or people do not tune in to their TV sets to follow the tournament. Some players have the mass appeal and crowds turn up to see their idols in action. They get high price even if their current form is a bit awry and they do not perform as is expected of them. These considerations need to be also included in the index. This is especially true for the big stars. People do know that once these big stars fire they are in for a treat of their lifetime. Efforts are being made in this direction.

\section{REFERENCES}

[1] Indian Premier League, https://en.wikipedia.org/wiki/Indian_Premier_League

[2] Clarke, S R, "Dynamic programming in one day cricket optimal scoring rates," Journal of the Operational Research Society, 50, 1988, pp 536 - 545.

[3] Kimber, A C and Hansford, A R, "A Statistical Analysis of Batting in Cricket," Journal of Royal Statistical Society, 156, 1993, pp $443-455$. 
[4] Norman, J and Clarke, S R, "Dynamic programming in cricket: Batting on sticky wicket," Proceedings of the 7th Australasian Conference on Mathematics and Computers in Sport, 2004, pp $226-232$.

[5] Ovens, $\mathrm{M}$ and Bukeit, B, "A mathematical modeling approach to one day cricket batting orders," Journal of Sports Science and Medicine, 5, 2006, pp 495-502.

[6] Lewis, A., "Extending the Range of Player-Performance Measures in One-Day Cricket," Journal of Operational Research Society, 59, 2008, pp 729-742.

[7] Saikia, Hemanta and Bhattacharjee Dibojyoti, "A Bayesian Classification Model for Predicting the Performance of All-Rounders in the Indian Premier League,http://papers.ssrn.com/sol3/papers.cfm?abstract_i $\mathrm{d}=1622060$.

[8] C. Deep Prakash, C.Patvardhan and Sushobhit Singh, "A new Machine Learning based Deep Performance Index for Ranking IPL T20 Cricketers", International Journal of Computer Applications (0975 - 8887) Volume 137 - No.10, March 2016.

[9] C. Deep Prakash, C.Patvardhan and Sushobhit Singh," A new Category based Deep Performance Index using Machine Learning for ranking IPL Cricketers", Int. Jl. of
Electronics, Electrical and Computational System IJEECS ISSN 2348-117X Volume 5, Issue 2 February 2016.

[10] C.Deep Prakash, "A New Team Selection Methodology using Machine Learning and Memetic Genetic algorithm for IPL-9", Int. Jl. of Electronics, Electrical and Computational System IJEECS ISSN 2348-117X Volume 5, Issue 4 April 2016.

[11] C. Deep Prakash, C. Patvardhan and C. Vasantha Lakshmi, "Team Selection Strategy in IPL-9 using Random Forests Algorithm", International Journal of Computer Applications (0975 - 8887) Volume 139 No.12, April 2016.

[12] http://www.rediff.com/cricket/report/icc-world-cup-devilliers-maintains-big-lead-shami-rises-to-7th-in-mostvaluable-player-table/20150320.htm

[13] http://www.espncricinfo.com/india/content/player/28081. html, T20 statistics of each player

[14] http://www.iplt20.com/teams/royal-challengersbangalore/squad/236/chris-gayle , IPL statistics of each player

[15] Leo Breiman. Random forests. Machine Learning, 45(1): 5-32, 2001 